\title{
Isolation and characterization of gingival fibroblasts positive for alkaline phosphatase in patients with chronic periodontitis and drug-induced gingival hyperplasia
}

\author{
Isolamento e caracterização de fibroblastos gengivais positivos \\ para fosfatase alcalina de pacientes portadores de periodontite \\ crônica e hiperplasia gengival medicamentosa
}

\begin{abstract}
Purpose: To investigate the expression of alkaline phosphatase (ALP) activity in gingival fibroblasts from individuals with chronic periodontitis (CP) and drug-induced gingival hyperplasia (DGH) induced by diphenylhydantoin.

Methods: Gingival fragments were obtained from 13 patients $(8$ women and 5 men, from 22 to 74 years of age), with 4 fragments from clinically normal gingiva (NG), 5 from biopsy of periodontal pockets with $\mathrm{CP}$, and 4 from DGH induced by diphenylhydantoin. Using an enzymatic digestion procedure, gingival cell suspensions containing ALP-positive fibroblasts were prepared without affecting ALP activity. Cytochemistry and histochemistry analyses were performed.

Results: Fibroblasts from NG presented low levels of ALP when compared to CP and DGH, which showed elevated and intermediate levels of ALP, respectively. Little cell proliferation was observed for fibroblasts from CP and DGH as compared to NG. However, the quantity of cells recovered from the subcultures was similar to the quantity recovered from the initial cell culture for the three sources.

Conclusion: The expression of ALP is increased in CP and DGH, and fibroblasts in CP and DGH show low proliferation. This suggests that periodontal inflammation and diphenylhydantoin may influence ALP expression and human gingival fibroblast expansion. Other studies are necessary to better assess the importance of ALP in the development and progression of CP and DGH.

Key words: Fibroblasts; alkaline phosphatase; periodontal disease; drug-induced gingival hyperplasia
\end{abstract}

\section{Resumo}

Objetivo: Investigar a expressão da atividade de fosfatase alcalina (ALP) em fibroblastos gengivais de sujeitos com periodontite crônica (PC) e hiperplasia gengival medicamentosa (HGM) induzida por difenilhidantoína.

Metodologia: Os fragmentos gengivais foram obtidos de 13 pacientes (8 mulheres e 5 homens, 22 a 74 anos), sendo 4 fragmentos procedentes de gengiva clinicamente normal (GN), 5 de biópsias de bolsas periodontais com PC e 4 de HGM induzida pela difenilhidantoína. Através de digestão enzimática, suspensões de células gengivais foram preparadas contendo fibroblastos ALP-positivos sem afetar a atividade da enzima ALP. Análises citoquímica e histoquímica foram realizadas.

Resultados: Fibroblastos de GN apresentaram fraca positividade para ALP quando comparados com PC e HGM. PC e HGM exibiram níveis elevados e intermediários, respectivamente, de ALP. Observou-se menor proliferação celular na cultura de células em PC e HGM que em GN. Entretanto, a quantidade de células recuperadas das sub-culturas foi similar à quantidade recuperada na cultura inicial para as três linhagens.

Conclusões: A expressão de ALP na PC e na HGM encontra-se aumentada e ocorre baixa proliferação de fibroblastos na PC e na HGM. Isto sugere que a inflamação periodontal e a difenilhidantoína podem influenciar a expressão de ALP e a multiplicação de fibroblastos gengivais humanos. Outros estudos são necessários para melhor avaliar a importância de ALP no desenvolvimento e na progressão de PC e HGM.

Palavras-chave: Fibroblastos; fosfatase alcalina; doença periodontal; hiperplasia gengival medicamentosa

\author{
Vagner Rodrigues Santos ${ }^{a}$ \\ Rafael Tomaz Gomes ${ }^{b}$ \\ Maurício Resende ${ }^{c}$ \\ Oslei Paes de Almeidad \\ Ricardo Della Colletad
}

\begin{abstract}
- Departamento de Clínica, Patologia e Cirurgia Odontológicas, Faculdade de Odontologia, UFMG, Belo Horizonte, MG, Brazil

b Curso de Medicina, Faculdade de Medicina, UFMG, Belo Horizonte, MG, Brazil

c Departamento de Microbiologia, Instituto de Ciências Biológicas, UFMG, Belo Horizonte, MG, Brazil

d Departamento de Diagnóstico Oral, Faculdade de Odontologia de Piracicaba, UNICAMP, Piracicaba, SP, Brazil
\end{abstract}




\section{Introduction}

Alkaline phosphatases (ALP) belong to the family of proteins bound to the cell membrane through glycosylphosphatidylinositol and hydrolyze a variety of monophosphate esters under high $\mathrm{pH}$ conditions (1). These enzymes are classified into four types of isoenzymes: intestinal, placental, placental-like, and tissue non-specific. Tissue non-specific ALP is observed in bone, liver, kidney, and oral tissues such as pulp and periodontal tissue (2).

The biological functions of tissue non-specific ALP include participation in bone mineralization (3); however, ALP is not a specific cellular marker of gingival fibroblasts in any periodontal disease. Previous studies have shown that fibroblasts from healthy human gingiva, like those from other tissues, have low levels of ALP activity $(4,5)$. Little is known about the phenotypic characteristics of gingival fibroblasts present in periodontal disease related to ALP expression; this lack of knowledge has complicated the understanding of the properties and functions of ALP in the physiopathology of periodontal tissue.

The objective of this study was to evaluate the phenotypic characteristics of fibroblasts obtained from gingival tissues from patients with chronic periodontitis $(\mathrm{CP})$ and druginduced gingival hyperplasia (DGH) through cytochemistry and histochemistry, with the purpose of analyzing the presence and activity of ALP.

\section{Methodology}

\section{Biopsy fragments}

This study was approved by the Ethics Committee of UFMG (protocol ETIC 150/99). Gingival fragments were obtained from 13 patients ( 8 women and 5 men) aged 22 to 74 years. Four fragments were from clinically normal gingiva (NG) (teeth indicated for extraction), 5 from biopsy of periodontal pockets with $\mathrm{CP}$ (gingivectomy), and 4 from

Table 1. List of subjects included in the present study with data on age, sex and gingival alteration. (Legend: $M=$ male, $F=$ female, $\mathrm{NG}=$ normal gingiva; $\mathrm{CP}=$ chronic periodontitis; $\mathrm{GH}=$ druginduced gingival hyperplasia).

\begin{tabular}{cccc}
\hline Patient & Sex & Age & Lesion \\
\hline 01 & $\mathrm{M}$ & 56 & $\mathrm{NG}$ \\
02 & $\mathrm{~F}$ & 74 & $\mathrm{NG}$ \\
03 & $\mathrm{~F}$ & 41 & $\mathrm{NG}$ \\
04 & $\mathrm{~F}$ & 38 & $\mathrm{NG}$ \\
05 & $\mathrm{~F}$ & 46 & $\mathrm{GH}$ \\
06 & $\mathrm{M}$ & 54 & $\mathrm{GH}$ \\
07 & $\mathrm{~F}$ & 50 & $\mathrm{GH}$ \\
08 & $\mathrm{~F}$ & 44 & $\mathrm{GH}$ \\
09 & $\mathrm{M}$ & 42 & $\mathrm{CP}$ \\
10 & $\mathrm{~F}$ & 22 & $\mathrm{CP}$ \\
11 & $\mathrm{M}$ & 29 & $\mathrm{CP}$ \\
12 & $\mathrm{M}$ & 28 & $\mathrm{CP}$ \\
13 & $\mathrm{~F}$ & 37 & $\mathrm{CP}$ \\
\hline
\end{tabular}

DGH induced by diphenylhydantoin (fragments removed for gingival correction). The summary of patients in this study is presented in Table 1.

The diagnosis of CP and DGH was based on clinical and radiographic aspects, and all cases complied with Armitage criteria (6). None of the patients presented history of recent systemic illness or took any medicine except for those who took diphenylhydantoin.

Before periodontal surgery, the patients received oral hygiene education, scaling and root smoothing. The degree of gingival inflammation immediately after the initial therapy was considered moderate to severe, according to clinical parameters of color, tissue consistency, and bleeding test results. The biopsies and gingival fragment sampling were done after area decontamination with $0.12 \%$ chlorohexidine gluconate solution.

\section{Isolation and primary culture of gingival fibroblasts}

The methods of sampling and isolation were based on those of Colleta et al. (7). The fragments were washed in physiological sodium chloride solution at $4^{\circ} \mathrm{C}$ and then divided into two parts. Fixation with $10 \%$ formalin was carried out on one of the fragment parts for further hematoxylin and eosin staining (HE), and histochemical study. The second fragment part was placed in a test tube filled with $10 \mathrm{~mL}$ DMEM cell culture medium (Sigma, USA) containing $125 \mu \mathrm{g} / \mathrm{mL}$ gentamicin, $50 \mathrm{ng} / \mathrm{mL}$ amphotericin B, and $10 \%$ heat-inactivated fetal bovine serum (Sigma, USA). Both parts were kept at $4^{\circ} \mathrm{C}$ for 10 hours. Each fragment was divided into smaller fragments, washed in supplemented DMEM, and left in tissue culture flasks (Falcon, USA) in a humidified $\mathrm{CO}_{2}$ incubator set at $37^{\circ} \mathrm{C}$ so that cell adhesion occurred.

Over a 15-day period, the growth media were changed every 2 days. After 15 days, trypsinization with $0.2 \%$ trypsin (Sigma, USA) was performed for 1 minute. To inactivate the activated trypsin, DMEM medium was added without amphotericin B. The cells in suspension were centrifuged for 4 minutes at $400 \mathrm{~g}$ in a refrigerated centrifuge. The pellet was resuspended in $1 \mathrm{dmL}$ DMEM supplemented with glutamine/gentamicin/SFB, of which $500 \mu \mathrm{L}$ was placed in 25-mL tubes.

Once the presence of cells was verified by phase contrast microscopy, the test tubes were incubated at $37^{\circ} \mathrm{C}$ in a humidified $\mathrm{CO}_{2}$ incubator. The growth media were replaced every 2 days. After the sixth passage, $2 \times 10^{6}$ cells/well were plated on 6-well culture plates (Falcon, USA). The cells were counted using a Neubauer Hemocytomere after using Trypan blue to stain the non-viable cells (Sigma, USA).

All cultures were supplemented with fetal bovine serum and antibiotics, and were incubated at $37^{\circ} \mathrm{C}$ in a humid atmosphere containing $5 \% \mathrm{CO}_{2}$. The culture medium was replaced every 2 days and, after confirming cellular confluence and the absence of microbial contamination, cytochemical tests were performed. Aliquots of the cellular suspension were mixed with Trypan blue, and the number of viable cells was counted using a hemocytometer. 


\section{Cytochemical study of ALP activity}

The cells were resuspended in DMEM/SFB, and after 3 hours of incubation for fixation and spreading onto 24-well plates, they were fixed with $0.1 \mathrm{M}$ sodium cacodylate buffer containing $1 \%$ paraformaldehyde and $5 \%$ sucrose, $\mathrm{pH} 7.4$, for 30 minutes at room temperature. After washing with cacodylate buffer, the cells were stained for ALP activity using a cytochemical medium containing 5- bromo-4-chloro3-indolylphosphate - BCIP (Sigma, USA) as the substrate, and nitro blue tetrazolium - NBT (Sigma, USA) as the staining agent. The BCIP-NBT method results in a bluish insoluble final product. Control samples were incubated in $1 \mathrm{mM}$ levamisole cytochemical medium (Sigma, USA), an ALP inhibitor. To distinguish cell surface ALP activity with cytoplasmic ALP activity, a group of cells was treated with and without phospholipase $\mathrm{C}$ specific for phosphatidylinositol (PI-PLC) (Sigma, USA), after washing with DMEM that did not contain SFB. After 2 hours of incubation with $\mathrm{CO}_{2}$ at $37^{\circ} \mathrm{C}$, the cells were prepared for ALP staining as described above.

\section{Histochemical study of ALP activity}

Some of the gingival fragments, after collection, were placed in PBS (phosphate-buffered saline; $0.01 \mathrm{M}, \mathrm{pH} 7.3$ ) at $4^{\circ} \mathrm{C}$, wrapped in aluminum foil, and put in the freezer at $-82^{\circ} \mathrm{C}$ until use. Histological sections with a thickness of $6.0 \mu \mathrm{m}$ were prepared using a cryostat (Cryostar, UK) at $-22^{\circ} \mathrm{C}$. For each fragment, four slides were prepared and stained in duplicate using HE and the histochemical technique. To show ALP activity, an azo dye associated with naphthol was used. The tissue sections were submerged in incubation solution at room temperature for 30 minutes. The incubation solution was made of $10 \mathrm{~mL}$ stock solution $25 \mathrm{mg}$ naphthol-AS-BI phosphate; $10 \mathrm{mLN}$ '-N'-dimethylformamide; $1.0 \mathrm{M}$ sodium carbonate (Sigma, USA); distilled water, 0.2 M Tris-HCL buffer; $\mathrm{pH}$ 8.3], to which $10 \mathrm{mg}$ of Fast Red TR Salt (Sigma, USA) was added. The tissue sections were then stained with Mayer's hematoxylin and mounted in glycerine gel (Sigma, USA). Positive and negative controls for the histochemical reaction consisted of specimens of mouse kidney and liver incubated in solutions with and without Fast Red TR Salt, respectively. The tissue sections were evaluated using an immersion objective (1000x). Alkaline phosphatase activity was assessed subjectively by one researcher, considering the location (epithelium and/or connective tissue) and intensity of the reactions: a) strongly positive (dark red), b) weakly positive (light pink), and c) absent.

\section{Results}

\section{Isolation of ALP-positive fibroblasts}

ALP-positive gingival fibroblasts were identified in NG, CP and DGH samples. Fibroblasts from NG presented weak or no ALP activity on the surface or in the cytoplasm. Moreover, the percentage of ALP-positive fibroblasts in both primary cultures and subcultures was low and the cells presented more rapid proliferation when compared to those from the $\mathrm{CP}$ and DGH gingiva.

The majority of CP fibroblasts exhibited elevated ALP activity observed as a granular product at the cytoplasmic membrane surface and in the cytoplasm. The percentage of ALP-positive fibroblasts was more elevated in both primary cultures and subcultures. The cellular proliferation was less than that of cells from the NG and DGH.

The majority of fibroblasts isolated from the DGH exhibited a strong cytoplasmic reaction for ALP, and much weaker or no superficial membrane reaction. The percentage of ALP-positive fibroblasts was lower in primary cultures and subcultures when compared to NG and CP. In addition, the cellular proliferation was lower than in NG, but similar to that observed for CP.

The fibroblasts were isolated from fragments of tissue based on their adherence to culture vessels. After the proliferation period in SFB, the adherent cells were flattened with different shapes, i.e., spherical, polygonal, or semi-circle, when observed under optical microscopy. The ALP-positive cells showed granular coloring around the nucleus and a uniform coloring distribution on the cellular surface. Control slides incubated in media containing levamisole were ALP-negative. Histochemical staining of tissue was also observed, with fibroblasts presenting ALP activity similar to that observed in cytochemical studies.

Experiments designed to differentiate cytoplasmic and intracytoplasmic membrane staining for ALP revealed only perinuclear staining. This granular perinuclear staining represents the intracellular expression of ALP, probably reflecting localization to the rough endoplasmic reticulum and/or Golgi apparatus. In contrast, uniform staining would correspond to ALP expression on the cytoplasmic membrane.

\section{Gingival fibroblast culture}

The cells in primary culture, and subsequently in subcultures (up to 6 passages), proliferated until confluence was observed between 6-7 days and 4-5 days for NG, 8-10 days and 5-7 days for $\mathrm{CP}$, and 7-8 days and 4-5 days for DGH in primary culture and subculture, respectively. The cells presented typical fibroblast characteristics, forming monolayers that inhibited proliferation through contact. The number of cells recovered from subcultures (6 passages) was similar for all three types of studied gingival tissue (Table 2).

Table 2. Percentage of alkaline phosphatase-positive gingival fibroblasts (ALP) recovered from sub-cultures (six passages) after the primary culture. (Legend: $\mathrm{NG}=$ normal gingiva; $\mathrm{CP}=$ chronic periodontitis; $\mathrm{GH}=$ drug-induced gingival hyperplasia).

\begin{tabular}{cccc}
\hline Sub-cultures & NG & CP & GH \\
\hline 01 & $75 \%$ & $80 \%$ & $80 \%$ \\
02 & $80 \%$ & $80 \%$ & $80 \%$ \\
03 & $80 \%$ & $85 \%$ & $75 \%$ \\
04 & $80 \%$ & $85 \%$ & $80 \%$ \\
05 & $80 \%$ & $80 \%$ & $80 \%$ \\
06 & $80 \%$ & $80 \%$ & $80 \%$ \\
\hline
\end{tabular}




\section{Histochemistry for ALP}

The fibroblasts from $\mathrm{CP}$ and DGH showed strong positivity for ALP activity, while NG fibroblasts were weakly positive or negative. Fibroblasts localized in the inflammatory area presented strong positivity when compared to those in a non-inflamed environment.

\section{Discussion}

Abe et al. (8) showed differential expression of alkaline phosphatase (ALP) activity in cell membranes of fibroblasts according to tissue localization in an ultra-structural study of chronically inflamed gingiva. The majority of fibroblasts in the inflamed connective tissue exhibited intense ALP activity, while fibroblasts in the non-inflamed adjacent connective tissue were slightly stained or showed no enzymatic membrane activity. In this study, ALP activity was only observed in adherent fibroblasts. ALP is recognized as a protein that binds to glycosyl-phosphatidyl-inositol. It is also known that this enzyme expressed in gingival fibroblasts is susceptible to cleavage by PI-PLC $(1,9)$. Thus, proteins bound to glycosyl-phosphatidyl-inositol are scarce in the cytoplasm and possess particular physical properties. For example, previous studies showed that ALP exhibits elevated lateral mobility over the cytoplasmic membrane plane (10). Therefore, the polarized localization of ALP membrane activity observed in vitro could describe a fast ALP distribution over adherent cells.

The fibroblast isolation procedure used in this study was based on that of Colleta et al. (7). However, our findings are similar to those found by Abe et al. (11) when fibroblasts collected from NG were compared with CP. These authors isolated alkaline phosphatase-positive fibroblasts from patients with $\mathrm{CP}$ and showed that it is possible to characterize these fibroblasts in vitro in subsequent cultures (11).

Trypsin was used during the six passages for subculture. The trypsin concentrations did not alter the biological behavior of the cells, and allowed the removal of other contaminating cells, such as epithelial and inflammatory cells, that also have alkaline phosphatase activity. This procedure was also important because fibroblasts from inflamed gingival tissue are primarily in contact with inflammatory cells and have decreased contact with collagen, as opposed to fibroblasts from healthy tissue that were observed in HE-stained sections and in agreement with Abe et al. (8). However, the isolation method used in this study is less aggressive for the cells than that used by Abe et al., and it enabled the recovery of a greater number of fibroblasts $\left(10^{6}-10^{8}\right.$ cells/patient).

Our work shows that ALP-positive gingival fibroblasts have less proliferation capacity than ALP-negative cells, as the proportion of ALP-positive fibroblasts decreased during cell culture. These findings are similar to those observed by Abe et al. (11) and demonstrate that in CP, gingival fibroblasts have low potential for growth. This is also consistent with previous in vitro studies showing reduced proliferative capacity for fibroblasts from chronically inflamed human gingiva and periodontium (11-13). However, with the exception of Abe et al., all studies, including ours, did not use phenotypic markers for identification of fibroblasts in inflamed tissues. According to Abe et al. (11), there are two important explanations for the difference in growth potential. One is that the DNA of ALP-positive gingival fibroblasts might be damaged by exposure to the inflammatory environment. The other explanation is that these cells might have a different trigger system of activation and differentiation. The second possibility is more probable, as fibroblasts, ultra-structurally ALP-positive both in vivo and in vitro, seem to be more metabolically active when quiescent than when cytopathologically altered. Furthermore, the repetitive treatment with PI-PLC of ALP-positive gingival fibroblasts in a 12-24 h period resulted in ALP expression in the cellular membrane, indicating that these cells actively produce ALP.

Previous studies suggest that ALP activity in gingival fibroblasts in the $\mathrm{CP}$ is induced by phenotypic changes induced by inflammatory conditions, rather than through selection and clonal expansion of a subpopulation of ALPpositive cells (8). The low proliferation capacity of ALPpositive cells excludes the possibility of a selective growth mechanism, and it is believed that an induced mechanism is involved (11).

Drug-induced gingival hyperplasia is a benign oral disease that causes progressive but non-hemorrhagic gingival growth (14). This disease is primarily caused by use of diphenylhydantoin, a drug commonly used as an anticonvulsant. The connective tissue under the epithelium, especially between the epithelium projections, manifested greater ALP activity in DGH than in NG. This suggests that the proliferation of fibroblasts in DGH is due to an increased effect of the epithelium either directly or indirectly on fibroblasts, resulting in greater ALP production. It is known that diphenylhydantoin induces changes in the conformation of the calcium binding site in ALP-nonspecific tissue; this can lead to phenotypic pattern changes, as calcium is important for ALP function.

It is still unclear whether the acquisition of ALP activity by gingival fibroblasts is relevant for their function. Evidence suggests that fibroblastic phenotype and differentiation are caused by local modulation induced by microenvironmental influences, allowing the cells to adapt to the specific area $(16,17)$. This theory of fibroblastic adaptation along with ALP expression in membrane of gingival fibroblasts may be related to gingival connective tissue repair in periodontal diseases, because ALP expression may be induced as a result of micro-environmental changes or the systemic effects of pharmaceuticals (8).

\section{Conclusions}

Gingival fibroblasts present increased ALP activity during inflammation (CP) and when under diphenylhydantoin action (DGH). The increased alkaline phosphatase activity in gingival fibroblasts in $\mathrm{CP}$ and DGH is associated with 
decreased proliferation of these cells, suggesting phenotypic changes caused by the micro-environment of CP and DGH. Other studies must be conducted to better evaluate the importance of ALP in the development and progression of $\mathrm{CP}$ and DGH.

\section{Acknowledgments}

This study was financially supported by FAPEMIG. We thank Prof. Ricardo Della Colleta (FOP-UNICAMP) and Prof. Maurício Resende (ICB-UFMG) for their collaboration.

\section{References}

1. Lisanti MP, Rodriguez-Boulan E, Saltiel AR. Emerging functional roles for the glycosyl-phosphatidylinositol membrane proteine anchor. J Membr Biol 1990;1 17:1-10.

2. Weiss MJ, Ray K, Henthorn PS, Lamb B, Kadesh T, Harris H. Structure of the human liver/bone/kidney alkaline phosphatase gene. J Biol Chem 1988;263:12002-10.

3. Harris $\mathrm{H}$. The human alkaline phosphatases: What we know and what we don't know. Clin Chim Acta 1990;186:133-50.

4. Somerman MJ, Archer SY, Imm GR, Foster RA. A comparative study of human periodontal ligament cells and gingival fibroblasts in vitro. J Dent Res 1988;67:66-70.

5. Piche JE, Carnes DL Jr, Graves DT. Initial characterization of cells derived from humam periodontia. J Dent Res 1989;68:761-7.

6. Armitage GC. Development of a classification system for periodontal diseases and conditions. Ann Periodontol 1999;4;1-6.

7. Colleta RD, Almeida OP, Graner E, Page RC, Bozzo L. Differential proliferation of fibroblasts cultured from hereditary gingival fibromatosis and normal gingiva. J Periodontal Res 1998;33: 469-75.

8. Abe T, Akamine A, Hara Y, Maeda K. Expression of membrane alkaline phosphatase activity on gingival fibroblasts in chronic inflammatory periodontal disease. J Periodontal Res 1994;29: 259-65.

9. Low MG. The glicosyl-phosphatidylinositol anchor of membrane proteins. Biochim Biophys Acta 1989;988:427-54.
10. Noda M, Yoon K, Rodan GA, Koppel DE. High lateral mobility of endogenous and transfected alkaline phosphatase: a phosphatidylinositol-anchored membrane protein. J Cell Biol 1987; 105:1671-7.

11. Abe T, Hara Y, Abe Y, Aida Y, Maeda K. Isolation of alkaline phosphatase-positive gingival fibroblasts from patients with chronic inflammatory periodontal disease. J Periodontal Res 1996;31:285-93.

12. Bartold PM, Page RC. Proteoglycans synthesized by cultured fibroblasts derived from normal and inflamed human gingiva. In Vitro Cell Dev Biol 1986;22:407-17.

13. Larjava H, Heino J, Kähäri VM, Krusius T, Vuorio E. Characterization of one phenotype of human periodontal granulation-tissue fibroblasts. J Dent Res 1989;68:20-5.

14. Huang JS, Ho KY, Chen CC, Wu YM, Wang CC, Ho YP, Liu CS. Collagen synthesis in idiopatic and dilantin-induced gingival fibromatosis. Kaohsiung J Med Sci 1997;13:141-8.

15. Mornet E, Stura E, Lia-Baldini AS, Stigbrand T, Ménez A, Le Du $\mathrm{MH}$. Structural evidence for a functional role of human tissue nonspecific alkaline phosphatase in bone mineralization. J Biol Chem $2001 ; 276: 31171-8$.

16. Komuro T. Re-evaluation of fibroblasts and fibroblast-like cells. Anat Embryol (Berl.) 1990;182:103-12.

17. Schmitt-Gräff A, Desmoulière A, Gabbiani G. Heterogeneity of myofibroblast phenotypic features: an example of fibroblastic cell plasticity. Virchows Arch 1994;425:3-24. 